\title{
Learning Tools Based On Connecting, Organizing, Reflecting And Extending (Core) Models For Class VIII Small Classes Valid
}

\author{
$1^{\text {st }}$ Sulis Ulianty $\mathrm{S}$ \\ Mathematics and Science Faculty \\ Universitas Negeri Padang \\ Padang, Indonesia \\ sulisembiring@gmail.com
}

\author{
$2^{\text {nd }}$ Ali Asmar \\ Mathematics and Science Faculty \\ Universitas Negeri Padang \\ Padang, Indonesia
}

\author{
$3^{\text {rd }}$ Budhi Oktavia \\ Mathematics and Science Faculty \\ Universitas Negeri Padang \\ Padang, Indonesia
}

\begin{abstract}
The purpose of this research is to discuss the learning tools based on the Connecting, Organizing, Reflecting and Extending (CORE) model for junior high school student, grade VIII. The development of learning tools is lesson plan and student worksheet by using model of Plomp. The subject of this research is students grade VIII, SMPN 15 Padang in 2017/2018. The instruments that are used in this research is validation sheet of lesson plan and student worksheet. They show that the learning tools based on CORE model is valid.
\end{abstract}

\section{Keywords: CORE Model, Learning Tool}

\section{INTRODUCTION}

Mathematical learning according to Nikson, suggests that learning mathematics is an effort to help learners in constructing the concepts or principles of mathematics with its own ability through internalization so that the concept or principle was reawakened [3]. This is in line with the objectives of mathematics learning based on the regulation of the Minister of Education and Culture of Indonesia No. 58 of 2014 is to understand the concept of mathematics, using patterns as conjecture in problem solving, reasoning, communicating ideas, having an appreciative, tenacious, confident, mathematical values, doing motor activities and or using props in solving problems.

Given the importance of the role of learning mathematics for learners, teachers are expected to optimize the existence and role of learners. To achieve this goal, teachers must be able to choose and apply the right way to ensure that learners can learn well. Teachers should be able to choose the right approach, strategy, model and / or teaching method to teach mathematics and to make learning more meaningful, easy to understand and useful for learners at this time and future life.
In the process of learning mathematics, thinking and reasoning ability are related to each other, because mathematics is a place for learners to solve a problem and gain the belief that to produce a right solution not only from the teacher, but also the logic of thinking and reasoning. Therefore the CORE learning model (Connecting, Organizing, Reflecting and Extending) is applied in learning to connect, organize, describe and convey the knowledge to the learners and expand their knowledge by conducting discussions during the learning process. Discussion method is a way of teaching by linking topics or issues that trigger the learners to try to reach or gain a decision and opinion mutually agreed.[4]

Calfee et al says that there are four things discussed in the CORE model of learning: First, the discussion determines the connections for learning; Second, the discussion helps organize the knowledge; Third, a good discussion can improve reflective thinking; and Fourth, discussions help broaden students' knowledge.[2]

\section{a. Connecting}

Connect language means to connect, connect, and connect. Katz and Nirula state that with Connecting a concept can be linked to other concepts in a class discussion, where the concepts to be taught are related to what the learners already know. So at this stage, learners are invited to connect new concepts to be learned with the old concept they have, by giving learners questions, then learners are asked to write related things from the question.

The connecting can be interpreted internally and externally. Internal is the linkage between mathematical concepts which relate mathematics itself and the linkage between mathematical concepts to daily life. Bruner suggests to produce successful learners, they should be given more opportunities to see the links between propositions and theories, 
theories and topics, concepts and concepts, as well as between branches of mathematics. Thus, to learn a new mathematical concept, the older concept also play a role in the successful of learning.

\section{b. Organizing}

At this stage, learners organize the information they acquire, such as what concepts are known, what concepts are sought, and the interconnectedness of what concepts are found in the Connecting stage to build their own knowledge. To organize the information, the learners conduct group discussions.

\section{c. Reflecting}

Reflect means describing and reflecting. Sagala reveals that reflection is a way of thinking back about what has been done in the past. Reflecting is an activity to rethink the information already obtained. At this stage students rethink the information they have acquired and understood at the Organizing stage. In the discussion activities, learners are given the opportunity to rethink whether the results of discussion is correct.

\section{d. Extending}

Extending is a stage where students can expand their knowledge of what has been gained during the learning proces. The extension of knowledge must be tailored to the conditions and abilities of the students. The extension of knowledge can be done by using the concept that has been gained into new situations or different contexts as the application of concepts studied, either from concept to other concepts, other fields of science, or into daily life. In the discussion activities, students are expected to expand their knowledge by working on questions related to the concepts but in the new situations or different contexts in groups.[2]

Learning tools are all tools and materials used by the teacher to support the smoothness and implementation of learning. Development of learning tools is a process to determine or create a certain condition that causes learners to interact in such a way that there is a change of behavior. In general, learning tools consist of Lesson Plan, learning resources (teacher books, student books, dictates, modules and the like), Student Worksheets, and learning test. Learning tools that will be developed in this study consist of Lesson Plan and Student Worksheet.

\section{METHODS}

The type of this research is Development Research. This study is used to develop a particular product, and test the validity of the product. The product developed is a mathematics learning tools in the form of Lesson Plan and Student Worksheet with CORE model for junior high grade VIII. In this study, the development model used is adapted from a model developed by Plomp and expressed as a Plomp development model. The Plomp development model consists of three stages: preliminary research, prototyping phase, and assessment phase.

Instrument validity is used to measure the validity of learning devices that have been developed. Aspects of assessment include aspects of presentation, content, language and appearance. The validation sheet of the device is filled by the validator with the rating scale using the Likert scale with the options: 1 for the strongly disagree statement, 2 for the disagree statement, 3 for the agree statement, and 4 for the statement strongly agree.

\section{a. Lesson Plan Validation Sheet}

The Lesson Plan validation sheet with the CORE model is used to validate the completeness and conformity of Lesson Plan components, language usage and Lesson Plan usability. The evaluation component of the Lesson Plan is spelled out in several assessment indicators. The validation sheet of Lesson Plan is validated by three validators. Validator provides an assessment of the Lesson Plan validation sheet with the CORE model.

\section{b. Student Worksheet Validation Sheet}

The CORE model-based Student Worksheet validation sheet is used to validate aspects of the presentation, content aspect, display aspect and language aspect. The Student Worksheet evaluation component is described in several assessment indicators. Student Worksheet validation sheet validated by three validators and has been revised.

Data derived from the validation sheet were analyzed using quantitative analysis. Validation results from validator to all aspects assessed will be presented in tabular form. The analysis was performed using a Likert scale. The validity analysis of learning tools based on the validation sheet is done in several steps:

a. Give the scoring scores as follows:

TABLE I. ASSESSMENT VALUES AGAINST LEARNING DEVICE VALIDITY

\begin{tabular}{|l|c|}
\hline Answer Alternative & Score \\
\hline Strongly Agree & 4 \\
\hline Agree & 3 \\
\hline Disagree & 2 \\
\hline Strongly Disagree & 1 \\
\hline
\end{tabular}

Determine the average value of the validity of each item by using Aiken's formula. [1] 


$$
V_{\mathrm{i}}=\frac{\sum_{j=1}^{n} s}{n(c-1)}
$$

information:

$$
\begin{aligned}
& V_{\mathbb{i}}=\text { indeks validitas item } \\
& s=r_{j}-l_{\mathbb{Q}} \\
& r_{\bar{j}}=\text { the score given by the validator for each item } \\
& l_{\mathbb{Q}}=\text { skor minimum (in this } \operatorname{case}^{l_{\mathbb{Q}}}=1 \text { ) } \\
& n=\text { many validators } \\
& c^{c}=\text { skor maksimum (in this case }{ }^{c}=4 \text { ) }
\end{aligned}
$$

Determine the validity of learning devices by calculating the average index of the validity of all items by the formula:

$$
V=\frac{\sum_{i=1}^{m} V_{i}}{m}
$$

informartion:

$$
\begin{aligned}
& V=\text { index of learning device validity } \\
& V_{\mathrm{i}}=\text { the score given by the validator for each item } \\
& m=\text { many item }
\end{aligned}
$$

Interpretation of learning device validity is determined by the following criteria:[1]

TABLE II. TOOL LEARNING VALIDITY CRITERIA
\begin{tabular}{|c|c|}
\hline Criteria & Interpretation \\
\hline$V<0,667$ & Invalid \\
\hline$V \geq 0,667$ & Valid \\
\hline
\end{tabular}

\section{RESULTS AND DISCUSSION}

Learning devices produced in this study are the Lesson Plan and Students Worksheets. Learning device products are developed based on CORE model (Connecting, Organizing, Reflecting and Extending). In this study, the development model used is adapted from a model developed by Plomp and expressed as a Plomp development model.

Based on the results of the analysis in Preliminary research stage was designed the development of learning devices based on CORE Model which is suitable for applied in grade VIII Semester II. Below is described the results of validation of learning tools by experts.

a. CORE model based Lesson Plan Validation Results

Validation of lesson plan is done by 4 validators consisting of 3 lecturers of mathematics and 1 lecturer of Indonesian language. During the validation process there are several revisions suggested by the validators. Referring to the suggestions given by the validator, there has been an improvement to the lesson plan based on the CORE model developed in order to obtain a better and valid RPP learning tool. After making improvements, the validators provide an assessment of the designed RPP. The CORE modelbased RPP validation results, presented in Table 3.

\section{TABLE III. LESSON PLAN VALIDATION RESULTS BASED ON CORE MODEL}

\begin{tabular}{|l|l|c|}
\hline No. & \multicolumn{1}{|c|}{ Validity Aspects } & $\begin{array}{c}\text { Validity } \\
\text { Index }\end{array}$ \\
\hline 1 & Subject Identity & 0,92 \\
\hline 2 & Basic Competency & 1,00 \\
\hline 3 & Formulation of learning indicators & 0,92 \\
\hline 4 & Formulation of learning purposes & 0,83 \\
\hline 5 & Selection of learning materials & 0,88 \\
\hline 6 & Selection of learning strategies & 0,89 \\
\hline 7 & Selection of learning sources & 0,83 \\
\hline 8 & Selection of learning media & 0,83 \\
\hline 9 & Procedure of learning process & 0,87 \\
\hline 10 & Evaluation & 0,83 \\
\hline 11 & Language and Writting & 0,88 \\
\hline 12 & Advantage of Lesson Plan & 0,83 \\
\hline \multicolumn{2}{|c|}{ Average of validity index } & 0,88 \\
\hline \multicolumn{2}{|c|}{ Category } & Valid \\
\hline
\end{tabular}

Based on table 3, it can be concluded that the overall Lesson Plan based CORE model already meets the valid criteria with the average validity index of 0.88 .

b. Student Worksheet Validation Result based on CORE model

Student Worksheet validation is performed by 5 validators ie 3 mathematics education experts, 1 Indonesian language expert and 1 educational technologist to validate the display aspect. After validation, Student Worksheet is improved based on suggestions provided by validators. After the correction, the validators provide an assessment of the designed Student Worksheet. Recapitulation of Student Worksheet validation result by validator is presented in table 4 .

TABLE IV. STUDENT WORKSHEET VALIDATION RESULTS CORE MODEL

\begin{tabular}{|l|l|c|}
\hline No & Validity Aspects & $\begin{array}{l}\text { Validity } \\
\text { Index }\end{array}$ \\
\hline 1 & Didactic and Subject & 0,88 \\
\hline 2 & Language & 0,90 \\
\hline 3 & Graphics & 0,67 \\
\hline \multicolumn{2}{|c|}{ Average of validity index } & 0,82 \\
\hline \multicolumn{2}{|c|}{ Category } & Valid \\
\hline
\end{tabular}

Based on Table 4, it can be seen that in general the validity of didactic aspects, aspects of language and graphics aspects already meet the valid criteria with the average index of validity is $0.88 ; 0.90$; and 0.67 . Overall validity of Students Worksheet based on 
CORE model has fulfilled the valid criteria with the average of the validity index as a whole 0.82 . So it can be concluded learning device based on CORE model developed can be said to be valid.

\section{CONCLUSIONS AND RECOMMENDATIONS}

\section{Conclusion}

This research is a development research that produces learning device based on Connecting, Organizing, Reflecting and Extending (CORE) model in the form of Lesson Plan and Student Worksheet. Learning tool developed based on four stages of CORE model is Connecting, Organizing, Reflecting and Extending by using Plomp development model [5]. The resulting mathematics learning tools were validated by 5 experts, namely 3 mathematics education experts, 1 educational technologist and 1 language expert. Based on the results of validation analysis of experts, it can be concluded that the learning devices based on CORE model developed have been valid in terms of both content and construct.

Recommendations

Teachers can use learning tools as an alternative to learning in class so that learners are not bored with the usual learning and classroom atmosphere of learning is more controllable. In addition, the development of CORE-based mathematics learning tools should be developed for other subjects in order to foster the interest of learners in mathematics learning by clearly explaining the four CORE components in each of the developed mathematics learning tools.

\section{REFERENCES}

[1] Azwar. Syaifudin, Validitas dan Reliablitas, Yogyakarta: Pustaka Pelajar, 2013.

[2] Jacob. C, Pengembangan Model 'CORE' dalam Pembelajaran Logika dengan Pendekaan Reciprocal Teaching bagi siswa SMA Negeri 9 Bandung dan SMA Negeri 1 Lembang (Laporan Piloting), Bandung: FPMIPA UPI, 2005.

[3] Muliyardi, Strategi Pembelajaran Matematika. Padang: FMIPA UNP, 2002.

[4] Nursidik.Y, Metode Diskusi Pembelajaran, 2008. Tersedia:

http://gapurapangarti.blogspot.com/2008/05/metodediskusipembelajaran.html [18 oktober 2017].

[5] Plomp. Tjeerd., Neinke. Nieveen, Educational Design Research, Part A: An Introduction. Enchede: SLO, 2013. 